\title{
PATHOPHYSIOLOGICAL FINDINGS ON BLOOD OF BEAGLES EXPERIMENTALLY INFECTED WITH BABESIA GIBSONI
}

\author{
Tsuyoshi Ishimine, Susumu Makimura, Sakujiro Kitazawa, \\ Satoru Tamura ${ }^{1}$ and Naoyoshi Suzuki
}

Received for publication 11 March 1978

\begin{abstract}
Severe hemolytic anemia was observed in the peripheral blood of beagles infected with B. gibsoni, in the acute stage of infection, with an increase of parasitized erythrocytes beginning on the 1st week postinfection. Haptoglobin concentration in the serum decreased remarkably up to the 2nd week postinfection, showing little or no haptoglobin in the serum on the 3 rd week to the 5 th week postinfection. An abrupt increase of monocytes and neutrophils in the acute stage was noted, showing degenerated figures with some vacucles in some cells. The beta and gamma globulins in the serum increased and albumin decreased remarkably in the acute stage. The gamma globulins remained at a level remarkably higher than the preinfection level until the 24th week postinfection. Rapid increase of IgM and IgG fluorescent antibody titers was noted on the 1st week postinfection, showing a tendency for relatively higher activity to continue to the 24 th week postinfection.
\end{abstract}

Recently, infection with Babesia (B.) gibsoni or B. sp. in dogs has been reported from various regions of Japan (Akashi et al., 1969; Kusunoki et al., 1971; Noda, 1977). B. gibsoni is reported to be smaller than B. canis with delicate ring forms. Aside from the size difference, it is known that hemoglobinuria, hemoglobinemia, icterus and consistent high fever, which are characteristic manifestations of acute B. canis infection, are not observed either in natural or in experimental infections with B. gibsoni (Ristic et al., 1971; Weinman and Ristic, 1968). In some cases, infections of the Babesiae are complicated by concurrent infections with other hemotropic agents such as Ehrlichia canis, Haemobartonella canis, and Hepatozoon canis. Mixed infections of Babesiae and E. canis often occur (Lewis and Ristic, 1977). For dogs in such conditions, the clinical signs, resulting from infection with $B$. gibsoni, which are less conspicuous than those observed in dogs infected with $B$. canis, are shown as different pathogenicity (Groves, 1972).

In spite of a large number of available reports on clinical and experimental canine babesiosis, information is very limited on the synthetic analysis of pathophysiological changes which are expressed as the body defense reaction of the host in babesial infection (Dorner, 1969; Schindler, 1970; Sibinovic, 1969). Consequently, as the first step of experimental studies on canine babesiosis, young beagles and 
mongrel dogs were set up to determine some of the pathophysiological changes of blood occurring in these dogs after infection with the parasites, using the same strain of B. gibsoni (Lewis and Ristic, 1977).

\section{Materials and Methods}

Babesia species: The strain of B. gibsoni (Lewis and Ristic, 1977) used in this study was originally obtained from a hunting dog that contracted the parasite in Hyogo Prefecture in Japan. This was maintained in the authors' laboratory in a deep freezer at $-80 \mathrm{C}$ and by dog passages during the experiments.

Experimental animals: Parasite free beagles from the colony maintained in a closed environment were used in the present study. Fourteen 90-day-old beagles from three litters produced by the same parent were used in the experiments. Four young mongrel dogs from the same parent, also 90-day-old, were used as control group. None of the beagles were vaccinated against distemper, rabies or canine hepatitis until the end of the experiments. Three healthy adult beagles, weighing approximately $15 \mathrm{~kg}$, harboring no protozoa in the blood, and inoculated with $B$. gibsoni four times in two years, were used as Babesia chronic beagles. To maintain regular conditions for breeding and feeding, each dog was put in separate cages, and was given a limited volume $(250 \mathrm{~g})$ of standard dog diet every day. Tap water was given freely during the experiment.

Experimental methods: The groups of beagles and mongrel dogs, all of which were 90-day-old, were all used in the experiments. Dogs were inoculated intravenously with approximately $1 \times 10^{9}$ parasitized erythrocytes which had been harvested from a splenectomized dog where in 30 per cent of the erythrocytes contained $B$. gibsoni. The suspension was made in $3 \mathrm{ml}$ physiological saline solution (PBS). As a diluent and anticoagulant, $0.005 \mathrm{mg}$ of heparin per $0.5 \mathrm{~m} l$ of blood was used. Three $\mathrm{m} l$ of blood were collected from each dog groups using the forearm vein. To collect serum samples, $2 \mathrm{~m} l$ of the blood were kept at $4 \mathrm{C}$ for 30 minutes, and then centrifuged at 3,000 rpm for 15 minutes. The resulting sera were stored at $-80 \mathrm{C}$ until used.

Measurement methods: Body temperatures of each dog were examined daily at 6 O'clock in the evening for 6 months. Erythrocytes were counted in a 1:100 dilution of blood samples in Hayem's solution, and white blood cells in a $1: 10$ dilution of blood sample in Turk's solution, by using the Neubauer hemocytometer. The hematocrit was measured by the capillary tube method, centrifuging at 12,000 rpm for 5 minutes. Hemoglobin concentration was measured by the cyanmethemoglobin method. The hemogram was studied microscopically with smears fixed in methanol and stained with May-Grünwald and Giemsa stains. The percentage of each type of leukocyte was calculated from a count of 200 cells. Reticulocytes were calculated from a count of 1,000 erythrocytes stained with 0.1 per cent brilliant cresyl blue. Total protein in serum was measured by the biurette method using a photometer. The protein fractions were ascertained by means of disc and acetate membrane electrophoreses. The staining of serum haptoglobin was estimated by the method described previously (Makimura and Suzuki, 1974a). Concentrations of immuno- 
globulins $M$ and $G$ in the sera were calculated by the immunodiffusion method. Antibody titers in the sera of the dogs against $B$. gibsoni were measured by the indirect fluorescent antibody test.

Indirect fluorescent antibody (IFA) test: Sera from dogs which recovered from B. gibsoni infections and fluorescein-conjugated rabbit anti-canine $\operatorname{Ig} M$ and $\operatorname{IgG}$, which were produced in the authors' laboratory, were used. Five $\mathrm{ml}$ of blood from dogs with 20 to 30 per cent erythrocytes infected with babesial parasites were collected in glass tubes. Thin blood films were prepared on microscope slides. The slides were separated by porous paper, sealed in a polyethylene bag and stored at $-80 \mathrm{C}$. When needed, the slides were placed in a desicator jar containing calcium chloride. The jar was evacuated, and the slides were warmed to room temperature. Each blood film was fixed in cooled acetone for 15 minutes, rinsed for 5 minutes in phosphate balanced saline solution (PBS), flooded with test serum on wet blotting paper in a covered petri dish and incubated at $37 \mathrm{C}$ for 30 minutes. The slides were rinsed again for 10 minutes in PBS, 5 minutes in distilled water, and then the fluorescein-conjugated anti-canine $\operatorname{IgM}$ and $\operatorname{IgG}$ were applied. Incubation and rinse procedures were repeated as described above. After rinsing the slides for 5 minutes in PBS, the stained slides were mounted with glycerin carbonate buffer ( $\mathrm{pH}$ 9.0) and examined as described (Hamashima and Yasuda, 1971).

\section{Results}

1. Variations of erythrocyte count, hemoglobin concentration, and packed cell volume (Figure 1).

The erythrocyte count, hemoglobin and packed cell volume (collectively referred to as RHP) were 7.0 million per cubic millimeter, $15.1 \mathrm{~g}$ per $100 \mathrm{ml}$ of blood, and 50.1 per cent before infection (b.i.), respectively, with an average of 5 experimental beagles. RHP in the beagles decreased remarkably to reach minimum values of 1.3 million, $3.1 \mathrm{~g}$ and 14 per cent on the $3 \mathrm{rd}$ week postinfection (p.i.). They then increased gradually to 2.9 million, $12.4 \mathrm{~g}$ and 44 per cent on the 13 th week p.i. Erythrocyte count and hematocrit remained at fixed values of 3.2 million and 41 per cent on the 24th p.i. In all experimental beagles, hemoglobinuria was observed on the 10 th to the 20 th day p.i.

In the group of 4 mongrel dogs, RHP showed a decrease until the 3 rd week p.i., reaching the minimum values of 2.7 million, $5.2 \mathrm{~g}$ and 16 per cent. They then increased gradually, showing values of 5.1 million and 32 per cent, respectively. The variation in RHP was slight as compared with those in beagles. Hemoglobinuria was not found in any of the 4 mongrel dogs throughout the experimental period.

2. Percentage of parasitized erythrocytes in peripheral blood (Figures 2 and 3).

Parasitemia levels were determined regularly by counting the number of parasitized cells in 1,000 erythrocytes on a thin film stained by the May-Grünwald and Giemsa. In beagles which were examined beyond 150 days p.i., as shown in Figures 


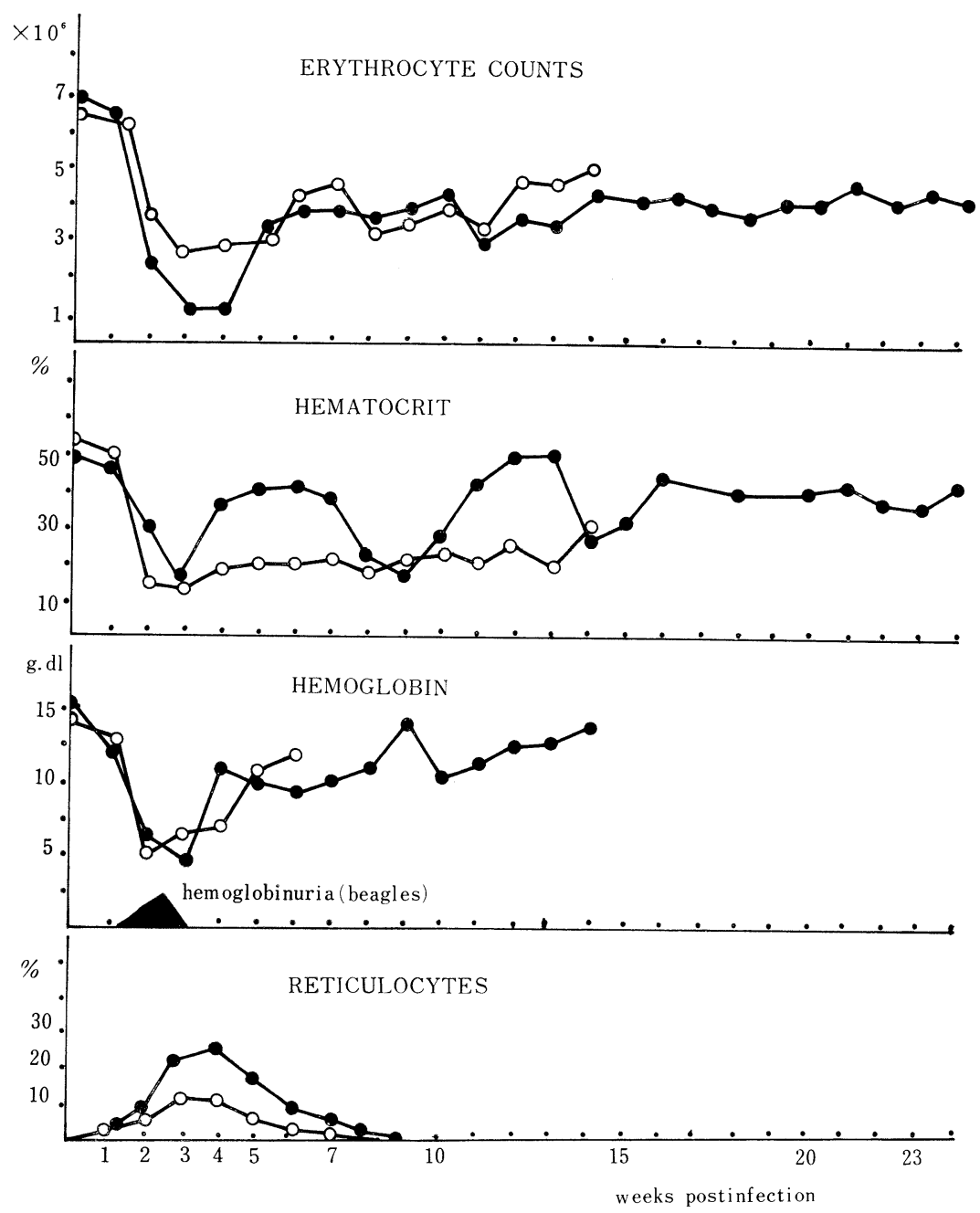

Figure 1 Changes in erythrocytes of dogs infected with B. gibsoni.

Remarks :

- Average of 5 beagles

O_ Average of 4 mongrel dogs

2 and 3, the first appearance of the parasites were detected in the blood approximately 7 days p.i., showing a maximum level of 19.5 per cent on the 21 st day p.i. They gradually disappeared until the 35 th day p.i. The second appearance of the parasites was observed approximately from the 7 th to the 13 th week p.i., showing a maximum level of 2.3 per cent on the 9 th to the 10 th week p.i. The parasite was not microscopically demonstrable in the peripheral blood until the 25 th week p.i. 


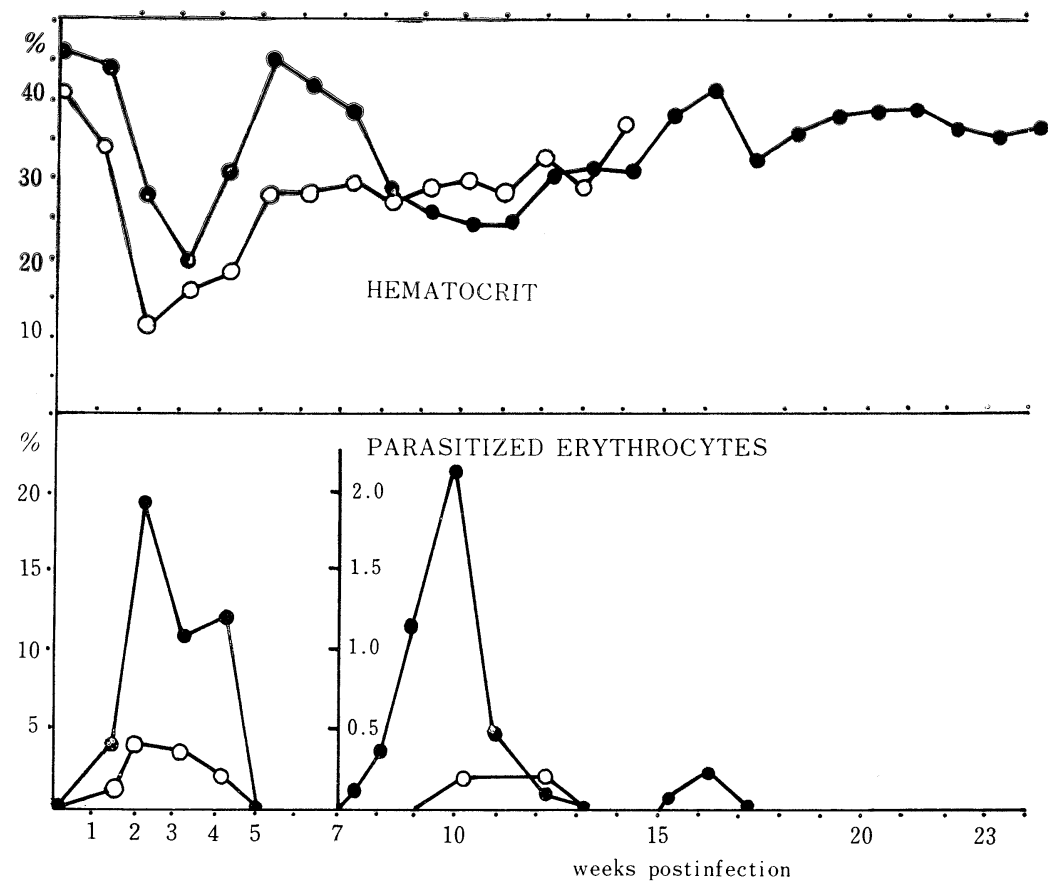

Figure 2 Appearance of the parasites in erythrocytes of dogs infected with B. gibsoni. Remarks: See Figure 1.

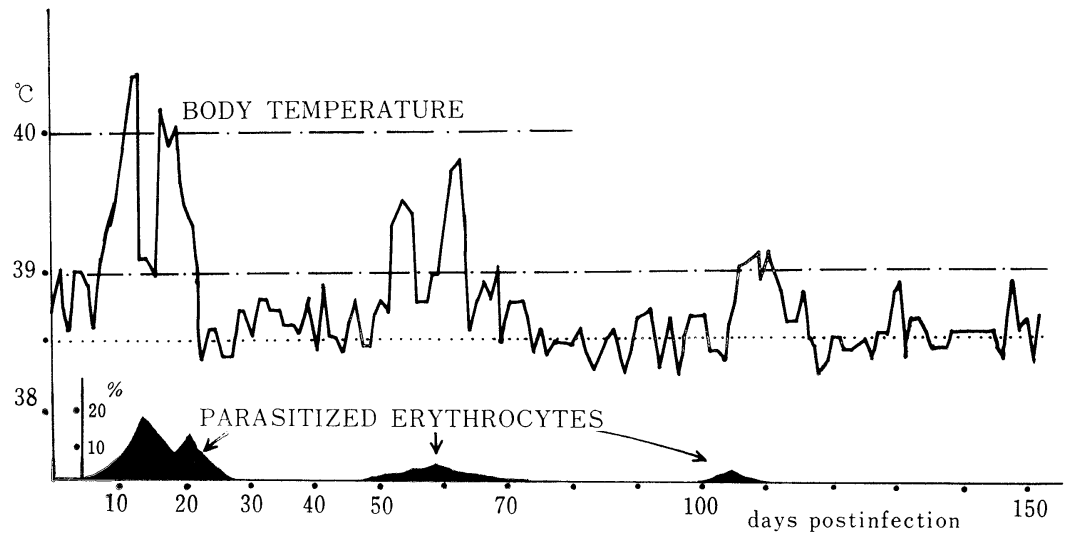

Figure 3 Changes in body temperature in a beagle infected with B. gibsoni.

3. Variation in white blood cell count and the differential leukocyte count (Figure 4).

The average leukocyte count in beagles, which was 5.8 thousand per cubic millimeter b.i., increased to 13.2 thousand on the $3 \mathrm{rd}$ week p.i., and decreased up 

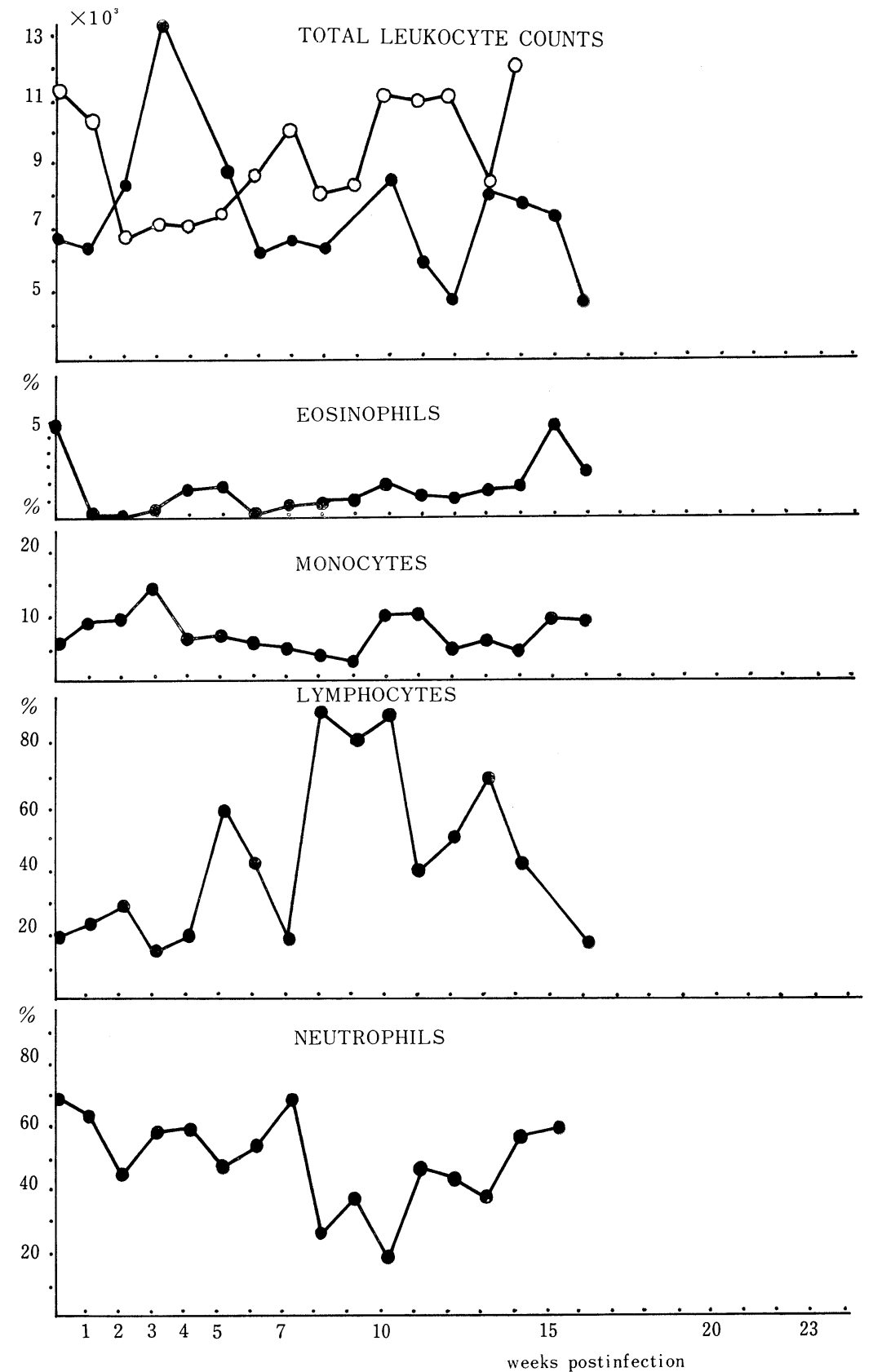

Figure 4 Changes in total and differential leukocyte counts in dogs infected with B. gibsoni. Remarks: See Figure 1. 
to the 15 th week p.i. In the differential leukocyte count, monocytes, which were 5.8 per cent b.i., showed an increase (15.4 per cent) on the 3 rd week p.i., and gradually decreased up to the 9 th week p.i. On the 10 th and 11 th weeks p.i., monocytes showed 11.8 to 12.3 per cent differential count. Lymphocytes, with 19.2 per cent differential count b.i., showed a tendency to increase above 80 per cent on the 8th to the 10 th weeks p.i.

4. Variation in total serum protein, protein fractions and haptoglobin in the serum (Figure 5 and Tables 1, 2 and 3).

As shown in Table 1, the average total serum protein of all the samples collected from 5 beagles decreased until the 3 rd week p.i. and increased gradually up to the 8th week p.i. Thereafter, it revealed a transient decrease twice and increased to

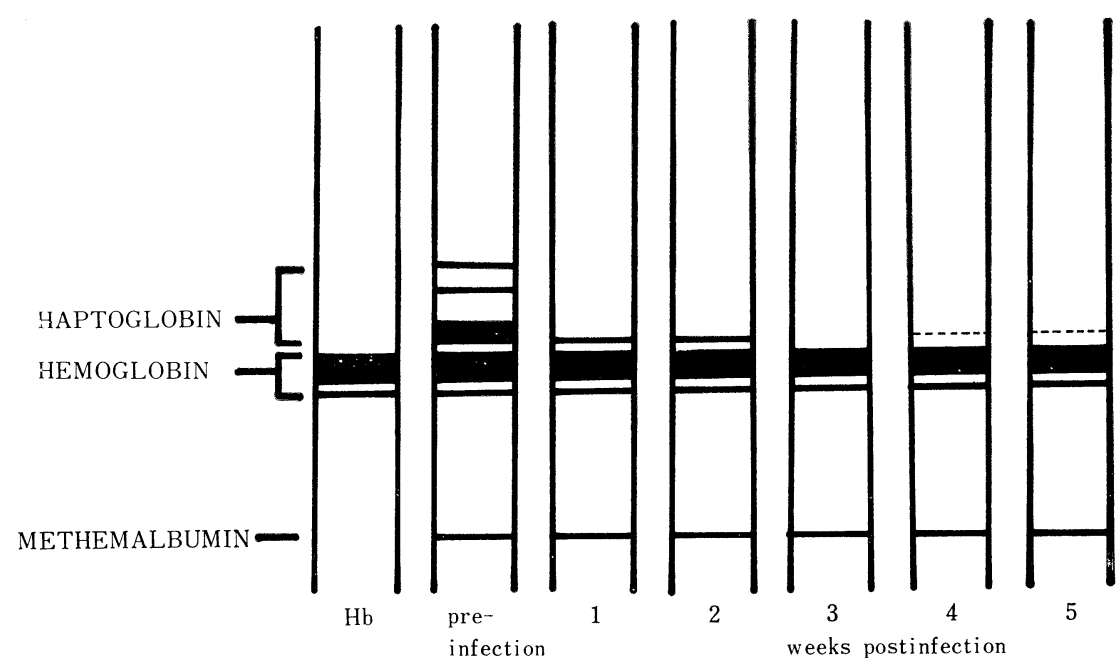

Figure 5 Changes of serum haptoglobin bands in a beagle infected with B. gibsoni.

Table 1 Changes in the average total protein and protein fractions in sera of five beagles infected with $B$. gibsoni

\begin{tabular}{lccccccccccccccc}
\hline Weeks postinfection & 0 & 1 & 2 & 3 & 4 & 5 & 6 & 7 & 8 & 10 & 11 & 13 & 18 & 21 & 24 \\
Total protein g/d $l$ & 6.0 & 6.0 & 5.4 & 4.8 & 6.0 & 6.8 & 5.8 & 6.0 & 6.5 & 4.8 & 4.0 & 7.2 & 5.0 & 6.8 & 6.8 \\
Protein fractions $\%$ & & & & & & & & & & & & & & & \\
Albumin (A) & 60 & 60 & 40 & 44 & 42 & 50 & 49 & 57 & 36 & 45 & 60 & 50 & 48 & 42 & 45 \\
Globulins (G) & 40 & 40 & 60 & 56 & 58 & 50 & 51 & 43 & 64 & 55 & 40 & 50 & 52 & 58 & 55 \\
alpha-1 & 5.4 & 2.8 & 3.4 & 3.3 & 2.2 & 2.9 & 4.4 & 3.3 & 2.5 & 3.2 & 2.7 & 4.6 & 1.5 & 4.0 & 3.0 \\
alpha-2 & 12.2 & 12.5 & 5.9 & 3.3 & 11.1 & 11.2 & 5.8 & 2.7 & 4.2 & 4.1 & 2.7 & 4.2 & 5.4 & 7.0 & 4.4 \\
beta & 20.8 & 19.8 & 21.7 & 24.7 & 27.6 & 26.4 & 29.4 & 23.4 & 16.1 & 15.4 & 20.0 & 15.5 & 17.9 & 18.8 & 12.3 \\
gamma & 2.7 & 4.0 & 28.5 & 24.7 & 18.6 & 9.9 & 14.7 & 13.4 & 41.0 & 32.1 & 13.7 & 25.9 & 27.4 & 27.7 & 30.8 \\
A/G ratio & 1.5 & 1.5 & 0.7 & 0.8 & 0.7 & 1.0 & 1.0 & 1.3 & 0.6 & 0.8 & 1.5 & 1.0 & 0.9 & 0.7 & 0.8 \\
\hline
\end{tabular}


Table 2 Changes in the average total protein and protein fractions in sera of four mongrel dogs infected with $B$. gibsoni

\begin{tabular}{lrrrrrrrrrrr}
\hline Weeks postinfection & \multicolumn{1}{c}{0} & \multicolumn{1}{c}{1} & 2 & 3 & 4 & 5 & 6 & 7 & 8 & 9 & 10 \\
Total protein g/d $l$ & 5.8 & 4.8 & 5.0 & 4.8 & 4.8 & 5.0 & 4.4 & 5.2 & 4.0 & 5.2 & 5.6 \\
Protein fractions \% & & & & & & & & & & & \\
Albumin (A) & 66 & 54 & 49 & 55 & 62 & 57 & 54 & 55 & 55 & 67 & 53 \\
Globulins (G) & 34 & \multicolumn{1}{c}{46} & 51 & 51 & 45 & 38 & 43 & 46 & 45 & 33 & 47 \\
alpha-1 & 6.6 & 6.6 & 9.0 & 4.4 & 6.6 & 5.6 & 6.3 & 4.3 & 6.7 & 3.4 & 3.2 \\
alpha-2 & 8.1 & 3.5 & 7.5 & 5.3 & 3.3 & 2.4 & 1.7 & 1.4 & 0.8 & 1.3 & 2.5 \\
beta & 16.2 & 20.5 & 22.6 & 25.3 & 23.6 & 16.9 & 17.8 & 25.8 & 19.5 & 18.4 & 30.6 \\
gamma & 2.2 & 15.3 & 11.3 & 16.3 & 11.8 & 12.0 & 17.2 & 14.3 & 18.0 & 8.9 & 10.5 \\
A/G ratio & 1.9 & 1.2 & 1.0 & 1.0 & 1.2 & 1.6 & 1.3 & 1.2 & 1.2 & 2.0 & 1.2 \\
\hline
\end{tabular}

Table 3 Serum concentration of IgM and IgG in a beagle infected with B. gibsoni

\begin{tabular}{lrrrrrrr}
\hline \multicolumn{2}{l}{$\begin{array}{l}\text { Days postinfection } \\
\text { Concentration of }\end{array}$} & 0 & 7 & 14 & 21 & 28 & 35 \\
IgM & & & & & & \\
$\mathrm{IgG}$ & $\mathrm{mg} / \mathrm{d} l$ & 172 & 188 & 222 & 252 & 260 & 302 \\
\hline
\end{tabular}

$4.0 \mathrm{~g}$ on the $11 \mathrm{th}$ and $7.2 \mathrm{~g}$ on the $13 \mathrm{th}$, and $5.0 \mathrm{~g}$ on the $18 \mathrm{th}$ and $6.8 \mathrm{~g}$ on the $24 \mathrm{th}$ week. The variations in the serum total protein in the beagles p.i. were opposite to those of the appearance of parasitized erythrocytes in the peripheral blood. When observation was made on each serum protein fraction, the albumin fraction decreased until the 4 th week p.i. It began to increase up to the 7 th week p.i. On the 8 th and 21st weeks p.i., it decreased remarkably, showing a similar tendency to those in the total serum protein. The alpha globulins, containing alpha 1 and 2, decreased gradually until the 24th week p.i. The beta globulins showed a tendency to increase up to the 6th week, and decreased gradually by the 24th week p.i. Gamma globulin showed a tendency to increase to a remarkable extent up to the 3 rd week p.i. and remained at a higher level than the preinfection level until the 24 th week p.i.

As for the changes of total serum protein and the fractions in four mongrel dogs (Table 2), total protein decreased gradually until the 8th week p.i., and a tendency to return to the preinfection value was observed. Although changes of albumin and globulin fractions in the mongrel dogs were not so remarkable, they showed a similar tendency to those in the beagles.

In one beagle examined for serum concentrations of $\operatorname{IgM}$ and $\operatorname{IgG}$ (Table 3), there was a tendency for the $\operatorname{IgM}$ and IgG to increase gradually up to the 35 th day p.i., showing a maximum concentration of both $302 \mathrm{mg}$ of IgM and 3,250 $\mathrm{mg}$ of IgG, respectively. The recorded serum concentration before infection was $172 \mathrm{mg}$ of IgM and $820 \mathrm{mg}$ of IgG per $100 \mathrm{~m} l$ serum.

In dogs infected with $B$. gibsoni, the concentrated stainability and the number of bands in serum haptoglobin patterns decreased gradually until the 3rd week p.i., 
showing no haptoglobin band in the serum on the 3rd week. Up to the 5 th week p.i., little or no haptoglobin was found in the serum. The period of disappearance of haptoglobin band in the serum was similar to that of the appearance of hemoglobinuria in the beagles.

5. Antibody responses measured by the indirect fluorescent antibody test (Table 4).

In the beagle Babesia antibodies were detected in both $\operatorname{IgM}$ and $\operatorname{IgG}$ on the 1 st week p.i. Their concentration increased sharply with a titer of $1: 320$ for $\operatorname{IgM}$ and $1: 2,560$ for $\operatorname{IgG}$ on the 5 th week and then gradually subsided to the level of $1: 40$ for $\operatorname{IgM}$ and $1: 320$ for IgG at 24 weeks after the onset of infection.

In the mongrel dogs infected with $B$. gibsoni, approximately the same response of the IFA antibodies was observed as compared with that in the beagles. The rise of the antibody titers was noted approximately 2 to 3 weeks after inoculation at approximately the same time as the first peak of parasites was detected in the peripheral blood films. There was also a noticeable tendency for both the $\operatorname{IgM}$ and IgG antibodies in the sera of the dogs examined to show relatively higher levels until the end of the experiments.

Table 4 Immunofuorascent antibody levels in sera of dogs infected with $B$. gibsoni

\begin{tabular}{|c|c|c|c|c|c|c|c|c|c|c|c|c|c|c|c|c|c|}
\hline \multicolumn{2}{|c|}{$\begin{array}{l}\text { Weeks } \\
\text { postinfection }\end{array}$} & 0 & & 2 & 3 & 4 & 5 & 6 & 7 & 8 & 9 & 10 & 11 & 13 & 18 & 21 & 24 \\
\hline \multicolumn{18}{|c|}{$\begin{array}{l}\text { Antibody levels } \\
\text { Beagles }\end{array}$} \\
\hline $\operatorname{IgM}$ & 1: & $<4$ & 40 & 160 & 160 & 320 & 80 & 20 & 20 & 20 & 20 & 40 & 40 & 40 & 40 & 80 & 40 \\
\hline $\mathrm{IgG}$ & $1:$ & $<4$ & 40 & 6401 & 1,2801 & 1,2802 & 2,5601, & 2801, & ,280 1 & 1,2801 & 1,2802, & 2,560 & 640 & 640 & 320 & 320 & 320 \\
\hline \multicolumn{18}{|c|}{ Mongrel dogs } \\
\hline IgM & 1: & $<4$ & 20 & 40 & 320 & 320 & 80 & 40 & 40 & 40 & 40 & 40 & & & & & \\
\hline $\operatorname{IgG}$ & 1: & $<4$ & 40 & 160 & 320 & 6401 & 1,2805 , & 1201 & ,280 & 640 & 640 & 640 & & & & & \\
\hline
\end{tabular}

\section{Discussion}

Severe hemolytic anemia was observed in the peripheral blood of beagles infected with $B$. gibsoni on the 2 nd to the 3 rd weeks p.i. Judging from the maximum level of parasitized erythrocytes in the acute stage of infection, the anemia might have been induced by the destruction of erythrocytes by parasites which had developed within these cells. There was a tendency for the anemia to vanish eventually in the chronic stage of infection. Generally hemoglobinuria with a severe hemolytic anemia in dogs is not observed either in natural or in experimental infections with B. gibsoni (Ristic et al., 1971; Weinman and Ristic, 1968; Noda, 1977). Mixed infections of $B$. gibsoni and $E$. canis often occur in some pathogenic cases. For such reason, the authors have asked Dr. Lewis' assistance to examine their samples for B. canis, $B$. gibsoni and $E$. canis (Lewis, 1977). The sample tested serologically was only positive for $B$. gibsoni, and negative for $B$. canis and E. canis. In consequence, the authors believed that the severe anemia in this experiment in beagles occurred through the 
infection of B. gibsoni alone. On the other hand, in mongrel dogs infected with B. gibsoni, no hemoglobinuria was observed in all cases. The decrease in serum haptoglobin level observed in the experimental beagles was remarkable on the 2nd to the 3rd week p.i. It is well known that all types of haptoglobin apparently have hemoglobin-binding capacities, making the haptoglobin-hemoglobin complexes. With regards to haptoglobin, any hemolytic anemia of significant severity, regardless of the mechanism of cell destruction, is usually associated with a lack or diminished level of haptoglobin (Harris, 1963). When haptoglobin is absent, unbound hemoglobin circulates in the blood, and is filtered by the glomerulus and passed on to the tubular system (Harris, 1963). Hemoglobinuria, found in experimental beagles, results after the resorptive capacity of the proximal renal tubules is exceeded.

In the present experiment, the beta and gamma globulins increased and albumin decreased remarkably in the acute stage. The gamma globulins remained at a level remarkably higher than that in the preinfection level until the 24 th week p.i. In such cases, serum concentration of $\operatorname{IgM}$ and $\operatorname{IgG}$ on the 5 th week p.i. increased approximately 3 times higher than that of preinfection. According to the report of Ristic (1971), in dogs infected with B. gibsoni, the rise of the indirect hemagglutination titers was noted approximately 22 days after inoculation at approximately the same time when the first parasites were detected in the peripheral blood films. The titers rose to the 4 th week after inoculation and then gradually subsided to the 5 th month after inoculation. With regards to humoral antibody responses, in this experiment rapid increase of IgM-fluorescent antibody titers were noted on the 1st week p.i., showing a tendency to increase up to the 4 th and 5 th weeks, and then declining gradually to a titer activity of $1: 40$ on the 24 th week p.i. A gradual increase of IgG-fluorescent antibody titer was also observed until the 5 th to the 7 th weeks, although having distinctly higher titers as compared with those of $\operatorname{IgM}$ until the 24th week p.i. The results obtained in the present study showed titers in both IgM and IgG antibody levels. These changes of antibody responses in dogs were similar to those noted in rats experimentally infected with Plasmodium berghei (Makimura et al., 1974b, c; Suzuki et al., 1973). However, there was no suggestion of replacement of $\operatorname{IgM}$ and $\operatorname{IgG}$ in this experiment as compared with that of Toxoplasma infected animals (Makimura et al., 1974b; Sethi et al., 1975; Shirahata et al., 1976; Soulsby, 1974; Suzuki et al., 1971).

It is unknown whether the changes of $\operatorname{IgM}$ and $\operatorname{IgG}$ antibody responses observed have been produced by the direct effect of the Babesia parasites. Further experiments should be performed to clarify the relationship between the changes of immune responses and the shifts of differential leukocyte counts in the peripheral blood.

\section{ACKNOWLedgements}

This study was supported by grant No. 044003 from the Scientific Research Fund of the Japanese Ministry of Education, Science and Culture. The authors wish to express their thanks to Dr. George E. Lewis and Professor Dr. M. Ristic, Department of Veterinary Pathology and Hygiene, University of Illinois, USA, for their valuable advice concerning the differential examination for B. canis, B. gibsoni 
and $E$. canis by indirect fluorescent antibody tests. Sincere appreciation is expressed for the valuable technical assistance given by all the staff of the Department of Veterinary Physiology, Obihiro University.

\section{References}

1) Akashi, M., Noda, R., Tomimura, T., Kotani, T., Shimakoshi, Y., Onishi, T. and Horie, M. (1969): Serum transaminase activity in dogs infected with B. gibsoni, Jap. J. Parasit., 18, 689690 (in Japanese)

2) Dorner, J. L. (1969): Clinical and pathologic features of canine Babesiosis, J. Amer. vet. Med. Ass., 154, 648-652

3) Groves, M. G. (1972): Babesia gibsoni field and laboratory studies of canine infections, Exp. Parasit., 31, 153-159

4) Hamashima, Y. and Yasuda, K. (1971): Fluorescent antibody technique and enzyme labeled antibody technique, Igaku Shoin Ltd., Tokyo (in Japanese)

5) Harris, J. W. (1963): The red cells, pp. 234-309, Harvard Univ. Press, Cambridge, Massachusetts, USA

6) Kusunoki, Y., Ito, Y., Okugi, M. and Osaki, F. (1971): A case of dog piroplasmosis in Tokushima city, Jap. J. Parasit., 20 (Sup. 2), 53 (in Japanese)

7) Lewis, G. E. and Ristic, M. (1977): Personal communications, March 23 and June 21

8) Makimura, S. and Suzuki, N. (1974a): A simple method for quantitative spectrophotometric determination of serum haptoglobin in mice and rats, Res. Bull. Obihiro Univ., 9, 49-55

9) Makimura, S., Umimura, S., Omata, Y. and Suzuki, N. (1974b): Variations on serum haptoglobin in mice experimentally infected with Plasmodium berghei and with Toxoplasma gondii, Res. Bull. Obihiro Univ., 8, 383-394

10) Makimura, S., Omata, Y., Kitazawa, S. and Suzuki, N. (1974c): Humoral antibody responses in rats experimentally infected with $P$. berghei yoelii, Res. Bull. Obihiro Univ., 9, 49-55

11) Noda, R. (1977): Canine babesiosis, J. Jap. vet. Med. Assoc., 30, 247-251 (in Japanese)

12) Ristic, M., Lykins, J. D. and Smith, A. R. (1971): Babesia canis and Babesia gibsoni, soluble and corpuscular antigen isolated from blood of dogs, Exp. Parasit., 30, 385-392

13) Schindler, R. (1970): Immunity and serological reactions after infections with Babesia, J. Parasit., 56, 306

14) Sethi, K. K., Pelster, B., Suzuki, N., Piekarski, G. and Brandis, H. (1975): Immunity to Toxoplasma gondii induced in vitro in nonimmune mouse macrophages with specifically immune lymphocytes, J. Immunol., 115, 1151-1158

15) Shirahata, T., Shimizu, K. and Suzuki, N. (1976): Effects of immune lymphocyte products and serum antibody on the multiplication of Toxoplasma in murine peritoneal macrophages, Zeit. f. Parasit., 49, 11-23

16) Sibinovic, K. H. (1969): In vivo and in vitro effects of serum antigen of Babesial infection and their antibodies on parasitized and normal erythrocytes, Ann. Trop. Med. Parasit., 63, 327-336

17) Soulsby, E. J. L. (1974): Parasitic Zoonoses, clinical and experimental studies. pp. 35-40, Academic Press, New York, USA

18) Suzuki, N., Piekarski, G., Janssen, P. and Viswanathan, R. (1971): Biochemical observations on blood of rats infected with T. gondii, Res. Bull. Obihiro Univ., 7, 15-25

19) Suzuki, N., Piekarski, G., Janssen, P. and Viswanathan, R. (1973): Pathophysiological observations on blood of rats infected with P. berghei, Jap. J. vet. Sci., 35, 367-376

20) Suzuki, N., Hirota, Y., Iijima, Y., Makimura, S., Tomoda, I. and Ishii, T. (1973): Studies on immunglobulins from normal and Toxoplasma-infected rat sera on DEAE-Sephadex A 50 in 
multilayer microcolumns, Jap. J. vet. Sci., 35, 279-287

21) Weinman, D. and Ristic, M. (1968): Infectious blood diseases of man and animals, Vol. II. pp. 219-268, Academic Press, New York, USA

実験的犬バベシア感染に伴うビーグル犬の病態生理学的所見

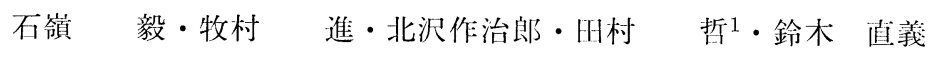

Babesia gibsoni 感染によるビーグル犬の血液一般性状, 体温の変動, および体液性抗体の推移につ いて実験的に検討した。

その結果, バベシア感染による90日柃ビーグル犬の一般臨床症状は同年跉の雑種犬に比較して極め て重く, 死亡例が観察された。

ビーグル犬では虫体含有赤血球が感染後 1 週に出現し， 5 週で末梢血液中から消失した。第 2 次お よび第 3 次虫体含有赤血球の出現は，それぞれ 7 週および 15 週に観察された。その出現率は第 1 次 が最も高く, 以後, 漸減した。血色素量および血球容積の減少は感染赤血球出現率の程度と逆傾向を 示した。血色素尿は感染後10〜20日目のビーグル犬に認められたが，雑種犬では実験全期間中全例に 検出されなかった。白血球の変動では単球がビーグル犬および雑種犬共に感染後 $2 \sim 3$ 週に著増した。 体温は末梢血液中に感染赤血球が出現する時期に一致して明らかな発熱が観察された。

ディスク電気泳動による血清ハプトグロビンは, 感染後 1 週より減少し 3 週では消失した。一方, 血清蛋白分画の変動では，アルブミンが感染後漸減し，グロブリンが増加した。とくに，rーグロブリ ンが著しく增加した。免疫グロブリン, IgM および IgG は，感染後 5 週で感染前に比較してそれぞ れ 3〜4倍に增加した。感染に伴う血清抗体の出現および推移では, IgM および IgG 抗体が感染後 1 週より共に全期間観察された。

帯広畜産大学家畜生理学教室 1 帯広音産大学家畜病理学教室 